\title{
Kajian Indeks Bias Terhadap Air Keruh Menggunakan Metode Plan Paralel
}

\author{
Suhadi $^{1^{*}}$, Nanda Septia Wiranda ${ }^{2}$, \\ ${ }^{1,2}$ Program Studi Pendidikan Fisika, FKIP Universitas Islam Negari Raden Fatah \\ Palembang 30251, Indonesia \\ *e-mail: suhadi@radenfatah.ac.id
}

\begin{abstract}
Abstrak
Berbagai cara yang bisa dilakukan untuk menentukan indeks bias zat cair, dari metode yang penggunaannya cukup rumit dan memerlukan banyak biaya, hingga yang mudah dan sederhana sebagai alternatif mengukur nilai indeks bias zat cair tersebut. Penelitian ini bertujuan untuk mengkaji indeks bias zat cair melalui metode plan paralel dengan menggunakan sampel air keruh yang berjenis koloid dan suspensi. Air yang tersuspensi pada penelitian ini, yaitu larutan pasir dan air berkoloid, yaitu limbah tahu. Hasil yang diperoleh pada penelitian ini menunjukkan bahwa indeks bias pada air berkoloid mendapatkan hasil dengan konsentrasi $100 \%$ air limbah pada sudut datang $15^{\circ}$ mendapatkan hasil sebesar 0,36 , pada $30^{\circ}$ mendapatkan hasil sebesar 0,86 , pada $45^{\circ}$ mendapatkan hasil sebesar 1,37 , pada $55^{\circ}$ mendapatkan hasil sebesar 1,76 dan pada $65^{\circ}$ mendapatkan hasil 2,14.dan air yang tersuspensi mendapatkan hasil sebesar, pada sudut datang $15^{\circ}$ mendapatkan hasil sebesar 1,13 , pada $30^{\circ}$ mendapatkan hasil sebesar 1,08 , pada $45^{\circ}$ mendapatkan hasil sebesar 1,09 , pada $55^{\circ}$ mendapatkan hasil sebesar 1,14 dan pada $65^{\circ}$ mendapatkan hasil 1,15 .
\end{abstract}

Kata Kunci: Air Keruh, Indeks Bias, Efek Tyndall.

\section{ASSESSMENT OF BIAS INDEX TO FAKE WATER USING THE PARARALEL PLAN METHOD}

\begin{abstract}
Various ways that can be done to determine the refractive index of liquids, from methods that use are quite complicated and require a lot of costs, to the easy and simple alternative to measure the refractive index value of the liquid. This study aims to examine the refractive index of liquid substances through a parallel plan method using a sample of colloidal and suspension turbid water. Water suspended in this study, which is a solution of sand and colloidal water, is tofu waste. The results obtained in this study indicate that the refractive index in colloidal water gets results with a concentration of $100 \%$ wastewater at an angle of arrival $15^{\circ}$ gets a yield of 0.36 , at $30^{\circ}$ gets a yield of 0.86 , at $45^{\circ}$ gets a yield of 1,37 , at $55^{\circ}$ gets a yield of 1.76 and at $65^{\circ}$ gets a yield of 2.14. And the suspended water gets a yield of, at the coming angle $15^{\circ}$ gets a yield of 1.13 , at $30^{\circ}$ gets a yield of 1,08 , at $45^{\circ}$ get a result of 1.09 , at $55^{\circ}$ get a result of 1.14 and at $65^{\circ}$ get a result of 1.15 .
\end{abstract}

Keywords: Turbid Water, Bias Index, Tyndall Effect 


\section{PENDAHULUAN}

Gelombang cahaya merupakan suatu ilmu fisika yang mempelajari tentang refleksi (pemantulan), refraksi (pembiasan), difraksi, interferensi, dan polarisasi cahaya. Pembiasan adalah peristiwa pembelokan arah rambat cahaya karena melalui medium yang berbeda kerapatannya. Apabila gelombang cahaya menumbuk antar muka (interface) halus yang memisahkan dua material transparan (tembus cahaya) seperti udara dan air atau air dan kaca, maka pada umumnya sebagian gelombang di pantulkan dan sebagian gelombang dipantulkan di dalam kedua material (Young et al, 2003).

Pembiasan merupakan kejadian fisika yang dapat dimanfaatkan keberadaannya dalam kehidupan. Peristiwa tersebut terjadi karena adanya perbedaan kerapatan medium yang dilalui oleh cahaya, sehingga terjadinya pembelokan cahaya. Perbandingan kecepatan cahaya pada ruang hampa dengan kecepatan cahaya pada suatu zat dinamakan indeks bias. Indeks bias suatu zat merupakan ukuran kelajuan cahaya di dalam zat cair dibanding ketika zat di udara (Murdaka et al, 2010).

Pengukuran indeks bias dalam industri dapat digunakan untuk menemukan parameter fisik berupa konsentrasi, suhu dan tekanan. Indeks bias juga dapat digunakan untuk mengetahui kualitas nilai dari suatu larutan. Penelitian yang dilakukan oleh Yunus dan Team (2009) menunjukan bahwa indeks bias dapat digunakan untuk menentukan kemurnian suatu zat dan kadarluarsa dari oli. Karena sudah banyaknya penelitian indeks bias untuk mengetahui kualitas suatu zat maka penelitian kali ini bertujuan untuk mengetahui indeks bias dengan air keruh yang ada disekitar lingkungan kita, yaitu limbah industri rumahan seperti limbah air tahu.
Kekeruhan adalah ukuran kejernihan relatif suatu cairan. Ini merupakan karakteristik optik dari air dan merupakan suatu pengukuran jumlah cahaya yang tersebar oleh material di dalam air ketika cahaya disinari melalui sampel air dan juga berkaitan dengan Efek Tyndall. Efek Tyndall terjadi karena cahaya tersebar oleh partikel yang ada dalam larutan koloid. Oleh sebab itu, dilakukanlah penelitian indeks bias pada air limbah tahu untuk memenuhi keingintahuan peneliti terhadap pengeruh kekeruhan air terhadap pembiasan cahaya.

Teknik yang digunakan dalam percobaan indeks bias ini menggunakan alat yang sederhana dan mudah dilakukan untuk mengukur indeks bias zat cair, yaitu metode pembiasan menggunakan plan paralel yang merupakan bangun tiga diemensi yang dibatasi oleh sisi-sisi yang sejajar yang transparan sehingga memudahkan cahaya yang terisi zat cair melakukan pembiasan.

\section{BAHAN DAN METODE}

\section{$>\quad$ Air Keruh (Turbid Water)}

Kekeruhan adalah kekaburan atau kabut cairan yang disebabkan oleh sejumlah besar partikel individu yang umumnya tidak dapat terlihat oleh mata telanjang, mirip dengan asap di udara.Pengukuran kekeruhan adalah ujian utama untuk mengetahui kualitas air. Cairan dapat mengandung zat padat tersuspensi yang terdiri dari partikel berbagai ukuran.Sementara beberapa bahan yang ditangguhkan akan cukup besar dan cukup berat untuk mengendap dengan cepat ke bagian bawah wadah jika sampel cair dibiarkan berdiri (bahan padat yang dapat diendapkan), partikel yang sangat kecil akan mengendap hanya dengan sangat lambat atau tidak sama sekali jika sampelnya adalah gelisah secara teratur atau partikelnya koloid. Partikel padat kecil ini menyebabkan 
cairan tampak keruh (Swanson and Baldwin, 1965).

Kekeruhan dalam air yang terbuka seperti sungai dan danau dapat disebabkan oleh pertumbuhan fitoplankton.Aktivitas manusia yang mengganggu tanah, seperti konstruksi, pertambangan, dan pertanian, dapat menyebabkan tingkat sedimen tinggi memasuki badan air selama badai hujan karena limpasanairhujanbadai.Daerah yang rentan terhadap erosi tepi tinggi serta daerah perkotaan juga berkontribusi besar terhadap kekeruhan air di sekitarnya, melalui polusi air hujan dari permukaan beraspal seperti jalan, jembatan dan tempat parkir.Beberapa industri seperti penggalian, penambangan, dan pemulihan batu bara dapat menghasilkan tingkat kekeruhan yang sangat tinggi dari partikel batuan koloid (Swanson and Baldwin, 1965).

Dalam air minum, semakin tinggi tingkat kekeruhan, semakin tinggi risiko orang terkena penyakit saluran cerna.Hal ini terutama bermasalah bagi orang yang mengalami gangguan sistem imun, karena kontaminan seperti virus atau bakteri dapat melekat pada padatan tersuspensi.Padatan tersuspensi mengganggu desinfeksi air dengan klorin karena partikelnya bertindak sebagai pelindung virus dan bakteri.Demikian pula, padatan tersuspensi dapat melindungi bakteri dari sterilisasi air ultraviolet (UV) (Swanson and Baldwin, 1965).

Badan air seperti danau, sungai, dan waduk, memiliki tingkat kekeruhan yang tinggi dapat mengurangi jumlah cahaya yang mencapai kedalaman yang lebih rendah, yang dapat menghambat pertumbuhan tanaman air yang terendam dan akibatnya memengaruhi spesies yang bergantung padanya, seperti ikan dan kerang.Tingkat kekeruhan yang tinggi juga dapat mempengaruhi kemampuan insang ikan untuk menyerap oksigen terlarut (Swanson and Baldwin, 1965).

$>$ Pembiasan (Refraksi)
Pembiasan merupakan peristiwa pembelokan arah rambat cahaya ketika memasuki ke suatu medium ke medium yang lain. Besarnya nilai pembiasan atau pembelokan arah rambat cahaya yang keluar dari suatu medium bergantung pada kerapatan optik medium tersebut. Kerapatan optik ini merupakan sifat dari medium yang tembus cahaya (zat optik) dalam melewatkan cahaya (Zamroni, 2013).

Cahaya yangmasuk dari zat optik kurang rapat ke zat optik lebih rapat (udara ke air), maka cahaya akan dibiaskan mendekati garis normal. Sebaliknya, jika cahaya masuk dari zat optik lebih rapat ke zat optik kurang (kaca ke udara), cahaya akan dibiaskan menjauhi garis normal. Garis normal merupakan garis yang tegak lurus pada bidang batas medium. Untuk lebih jelasnya, perhatikan gambar di bawah ini;

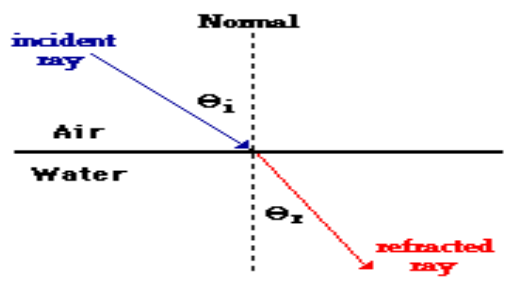

Gambar 2.1 Pembiasan Cahaya pada Zat Cair

Besar nilai kerapatan optik suatu medium dinyatakan dalam indeks bias. Itu artinya semakin besar indeks bias suatu medium berarti kerapatan optik medium juga semakin besar dan semakin besar kerapatan optik, maka akan semakin besar pula arah pembelokan cahaya yang melewati medium tersebut (Zamroni, 2013).

Setiap medium mempunyai indeks bias tertentu, yang merupakan suatu ukuran seberapa besar nilai suatu bahan dapat membiaskan cahaya. Indeks biassuatu zat adalah perbandingan kecepatan cahaya di udara dengan kecepatan cahaya di dalam zat tersebut. Kecepatan cahaya di udara selalu lebih besar daripada di dalam zat lain. Oleh 
karena itu, indeks bias zat lain selain udara selalu lebih besar dari 1 (Utami, 2015).

Semakin besar indeks bias suatu zat maka semakin besar cahaya dibiaskan oleh zat tersebut. Besarnya pembiasan juga bergantung pada panjang gelombang cahaya. Pada spektrum cahaya tampak, panjang gelombang cahaya memiliki variasi gelombang, merah yang terpanjang sampai gelombang ungu yang terpendek (Utami, 2015).

Ketika cahaya dari satu medium merambat melewati medium lainnya yang berbeda kerapatan optik maka cepat rambat cahaya akan berubah. Cepat rambat cahaya akan berkurang jika memasuki medium dengan kerapatan tinggi. Sebaliknya, cepat rambat cahaya akan bertambah jika melewati medium dengan kerapatan rendah.

Perbandingan cepat rambat cahaya di ruang hampa (c)dengan cepat rambat cahaya di dalam suatu medium disebut indeks bias mutlak. Indeks bias mutlak suatu medium dapat dicari dengan menggunakan persamaan dibawah ini.

$$
n=\frac{c}{v} \ldots \ldots \text { pers } 1
$$

\section{Keterangan:}

$n=$ indeks bias mutlak medium

$c=$ cepat rambat cahaya di ruang

hampa yaitu $\left(3 \times 10^{8} \mathrm{~m} / \mathrm{s}\right)$

$v=$ cepat rambat cahaya di dalam

medium

Analisis data dilakukan menggunakan hukum Snellius:

$$
\begin{aligned}
& \frac{\sin \theta_{1}}{\sin \theta_{2}}=\frac{v_{1}}{v_{2}}=\frac{n_{2}}{n_{1}} \\
& \text { atau } \\
& n_{1} \sin \theta_{1}=n_{2} \sin \theta_{2} \ldots \ldots \ldots \ldots . . . \text { Pers } 2 \\
& n_{1}=\text { indeks bias medium pertama } \\
& \theta_{1}=\text { sudut datang } \\
& n_{2}=\text { indeks bias medium kedua } \\
& \theta_{2}=\text { sudut bias }
\end{aligned}
$$

Berikut ini merupakan beberapa contoh dari indeks bias mutlak medium yang disajikan dalam bentuk tabel.
Tabel 2.1 Indeks Bias Mutlak

Berbagai Medium

\begin{tabular}{|l|l|}
\hline Medium & $\begin{array}{l}\text { Indeks } \\
\text { Bias }\end{array}$ \\
\hline $\begin{array}{l}\text { Ruang } \\
\text { (vakum) }\end{array}$ & 1,0000 \\
\hline Udara & 1,0003 \\
\hline Es & 1,3100 \\
\hline Air $\left(20^{\circ}\right.$ C) & 1,3300 \\
\hline Etil alkohol & 1,3600 \\
\hline Kaca kwartz & 1,4590 \\
\hline Kuarsa & 1,4600 \\
\hline Gliserin & 1,4700 \\
\hline Benzena & 1,5010 \\
\hline Kaca plexi & 1,5100 \\
\hline Kaca kerona & 1,5200 \\
\hline Kaca flinta & 1,6200 \\
\hline Batu nilam & 1,7600 \\
\hline Intan & 2,4200 \\
\hline
\end{tabular}

\section{METODOLOGI PENELITIAN}

Alat dan bahan dalam penelitian ini adalah Sepotong papan, Alas karton, Kaca plan parallel berisi air sebagai media penelitian dengan ketebalan $1 \mathrm{~mm}$, Busur, Pensil, Penggaris dan Kertas HVS/folio. Adapun paameter peneltiian ini adalah mengukur indeks bias zat cair pada air keruh dengan menggunakan metode sederhana.

Berisi jenis penelitian, waktu dan tempat penelitian, target/sasaran, subjek penelitian, prosedur, instrumen dan teknik analisis data serta hal-hal lain yang berkait dengan cara penelitiannya. target/sasaran, subjek penelitian, prosedur, data dan instrumen, dan teknik pengumpulan data, serta teknik analisis data serta hal-hal lain yang berkait dengan cara penelitiannya dapat ditulis dalam sub-subbab, dengan subsubheading. Sub-subjudul tidak perlu diberi notasi, namun ditulis dengan huruf kecil berawalkan huruf kapital, TNR-12 unbold, rata kiri.

Khususnya untuk penelitian kualitatif, waktu dan tempat penelitian 
perlu dituliskan secara jelas (untuk penelitian kuantitatif, juga perlu). Target/subjek penelitian (untuk penelitian kualitatif) atau populasi-sampel (untuk penelitian kuantitatif) perlu diurai dengan jelas dalam bagian ini. Perlu juga dituliskan teknik memperoleh subjek (penelitian kualitatif) dan atau teknik samplingnya (penelitian kuantitatif).

Prosedur perlu dijabarkan menurut tipe penelitiannya. Bagaimana penelitian dilakukan dan data akan diperoleh, perlu diuraikan dalam bagian ini.

Untuk penelitian eksperimental, jenis rancangan (experimental design) yang digunakan sebaiknya dituliskan di bagian ini. Macam data, bagaimana data dikumpulkan, dengan instrumen yang mana data dikumpulkan, dan bagaimana teknis pengumpulannya, perlu diuraikan secara jelas dalam bagian ini.
Bagaimana memaknakan data yang diperoleh, kaitannya dengan permasalahan dan tujuan penelitian, perlu dijabarkan dangan jelas.

(Catatan: Sub-subbab bisa berbeda, menurut jenis atau pendekatan penelitian yang digunakan. Jika ada prosedur atau langkah yang sifatnya sekuensial, dapat diberi notasi (angka atau huruf) sesuai posisinya).

\section{HASIL DAN PEMBAHASAN}

A. HASIL

Dari penelitian diperoleh data pengukuran yang dapat dilihat pada tabel 4.1, sebagai berikut:

Tabel 4.1 Data Hasil Pengukuran Indeks Bias Zat Cair.

Dari penelitian diperoleh data pengukuran yang dapat dilihat pada tabel 4.1 , sebagai berikut:

Tabel 4.1 Data Hasil Pengukuran Indeks Bias Zat Cair

\begin{tabular}{|c|c|c|c|c|c|c|c|}
\hline no & $\begin{array}{l}\text { Zat } \\
\text { Cair }\end{array}$ & $\begin{array}{l}\text { Perc } \\
\text { Ke.. }\end{array}$ & $\begin{array}{l}\text { Sudut } \\
\text { Datang } \\
\left(\theta_{1}\right)\end{array}$ & $\begin{array}{l}\text { Sin } \\
\theta_{1}\end{array}$ & $\begin{array}{l}\text { Sudut } \\
\text { Bias } \\
\left(\theta_{2}\right)\end{array}$ & $\begin{array}{l}\text { Sin } \\
\theta_{2}\end{array}$ & $\begin{array}{l}\text { Indeks } \\
\text { Bias } \\
\text { (n) }\end{array}$ \\
\hline \multirow[t]{5}{*}{1} & \multirow[t]{5}{*}{ Air Biasa } & 1 & $15^{\circ}$ & 0,25 & $11^{\circ}$ & 0,19 & 1,31 \\
\hline & & 2 & $30^{\circ}$ & 0,50 & $22^{\circ}$ & 0,37 & 1,35 \\
\hline & & 3 & $45^{\circ}$ & 0,70 & $32^{\circ}$ & 0,52 & 1,34 \\
\hline & & 4 & $55^{\circ}$ & 0,81 & $37^{\circ}$ & 0,60 & 1,35 \\
\hline & & 5 & $65^{\circ}$ & 0,90 & $42^{\circ}$ & 0,66 & 1,36 \\
\hline \multirow[t]{5}{*}{2} & \multirow{5}{*}{$\begin{array}{l}\text { Limbah } \\
\text { Air Tahu } \\
\text { (Air } \\
\text { Turbid) }\end{array}$} & 1 & $15^{\circ}$ & 0,25 & $44^{\circ}$ & 0,69 & 0,36 \\
\hline & & 2 & $30^{\circ}$ & 0,50 & $36^{\circ}$ & 0,58 & 0,86 \\
\hline & & 3 & $45^{\circ}$ & 0,70 & $31^{\circ}$ & 0,51 & 1,37 \\
\hline & & 4 & $55^{\circ}$ & 0,81 & $28^{\circ}$ & 0,34 & 1,76 \\
\hline & & 5 & $65^{\circ}$ & 0,90 & $25^{\circ}$ & 0,42 & 2.14 \\
\hline \multirow[t]{5}{*}{3} & \multirow{5}{*}{$\begin{array}{l}\text { Campura } \\
\text { n Limbah } \\
\text { dan Air } \\
\text { Biasa } \\
(20: 80)\end{array}$} & 1 & $15^{\circ}$ & 0,25 & $18^{\circ}$ & 0,30 & 0,83 \\
\hline & & 2 & $30^{\circ}$ & 0,50 & $33^{\circ}$ & 0,54 & 0,92 \\
\hline & & 3 & $45^{\circ}$ & 0,70 & $48^{\circ}$ & 0,74 & 0,94 \\
\hline & & 4 & $55^{\circ}$ & 0,81 & $57^{\circ}$ & 0,83 & 0,97 \\
\hline & & 5 & $65^{\circ}$ & 0,90 & $65^{\circ}$ & 0,90 & 1 \\
\hline 4 & Campura & 1 & $15^{\circ}$ & 0,25 & $35^{\circ}$ & 0,57 & 0,43 \\
\hline
\end{tabular}


Kajian Indeks Bias...Jupiter... Vol 1 No 1...Juli 2019...7-14

Suhadi, Nanda SeptiaWiranda

\begin{tabular}{|c|c|c|c|c|c|c|c|}
\hline \multirow{4}{*}{\multicolumn{2}{|c|}{\begin{tabular}{|l|l} 
n Limbah \\
dan Air \\
Biasa \\
$(50: 50)$
\end{tabular}}} & 2 & $30^{\circ}$ & 0,50 & $23^{\circ}$ & 0,39 & 1,28 \\
\hline & & 3 & $45^{\circ}$ & 0,70 & $20^{\circ}$ & 0,34 & 2.05 \\
\hline & & 4 & $55^{\circ}$ & 0,81 & $18^{\circ}$ & 0,30 & 2.7 \\
\hline & & 5 & $65^{\circ}$ & 0,90 & $17^{\circ}$ & 0,29 & 3.10 \\
\hline \multirow[t]{5}{*}{5} & \multirow{5}{*}{$\begin{array}{l}\text { Campuran } \\
\text { Limbah } \\
\text { dan Air } \\
\text { Biasa } \\
(80: 20)\end{array}$} & 1 & $15^{\circ}$ & 0,25 & $39^{\circ}$ & 0,62 & 0,40 \\
\hline & & 2 & $30^{\circ}$ & 0,50 & $35^{\circ}$ & 0,57 & 0,87 \\
\hline & & 3 & $45^{\circ}$ & 0,70 & $33^{\circ}$ & 0,54 & 1,29 \\
\hline & & 4 & $55^{\circ}$ & 0,81 & $32^{\circ}$ & 0,52 & 1,55 \\
\hline & & 5 & $65^{\circ}$ & 0,90 & $30^{\circ}$ & 0,50 & 1.8 \\
\hline \multirow[t]{5}{*}{6} & \multirow{5}{*}{$\begin{array}{l}\text { Larutan } \\
\text { Pasir }\end{array}$} & 1 & $15^{\circ}$ & 0,25 & $13^{\circ}$ & 0,22 & 1,13 \\
\hline & & 2 & $30^{\circ}$ & 0,50 & $28^{\circ}$ & 0,46 & 1,08 \\
\hline & & 3 & $45^{\circ}$ & 0,70 & $40^{\circ}$ & 0,64 & 1,09 \\
\hline & & 4 & $55^{\circ}$ & 0,81 & $46^{\circ}$ & 0,71 & 1,14 \\
\hline & & 5 & $65^{\circ}$ & 0,90 & $52^{\circ}$ & 0,78 & 1,15 \\
\hline
\end{tabular}

\section{B. GRAFIK}

Dari penelitian diperoleh data pengukuran yang dapat dilihat pada tabel
4.1, diatas, dan disajikan pada grafik di bawah ini:

Grafik 4.1 Data Hasil Pengukuran Indeks Bias Zat Cair

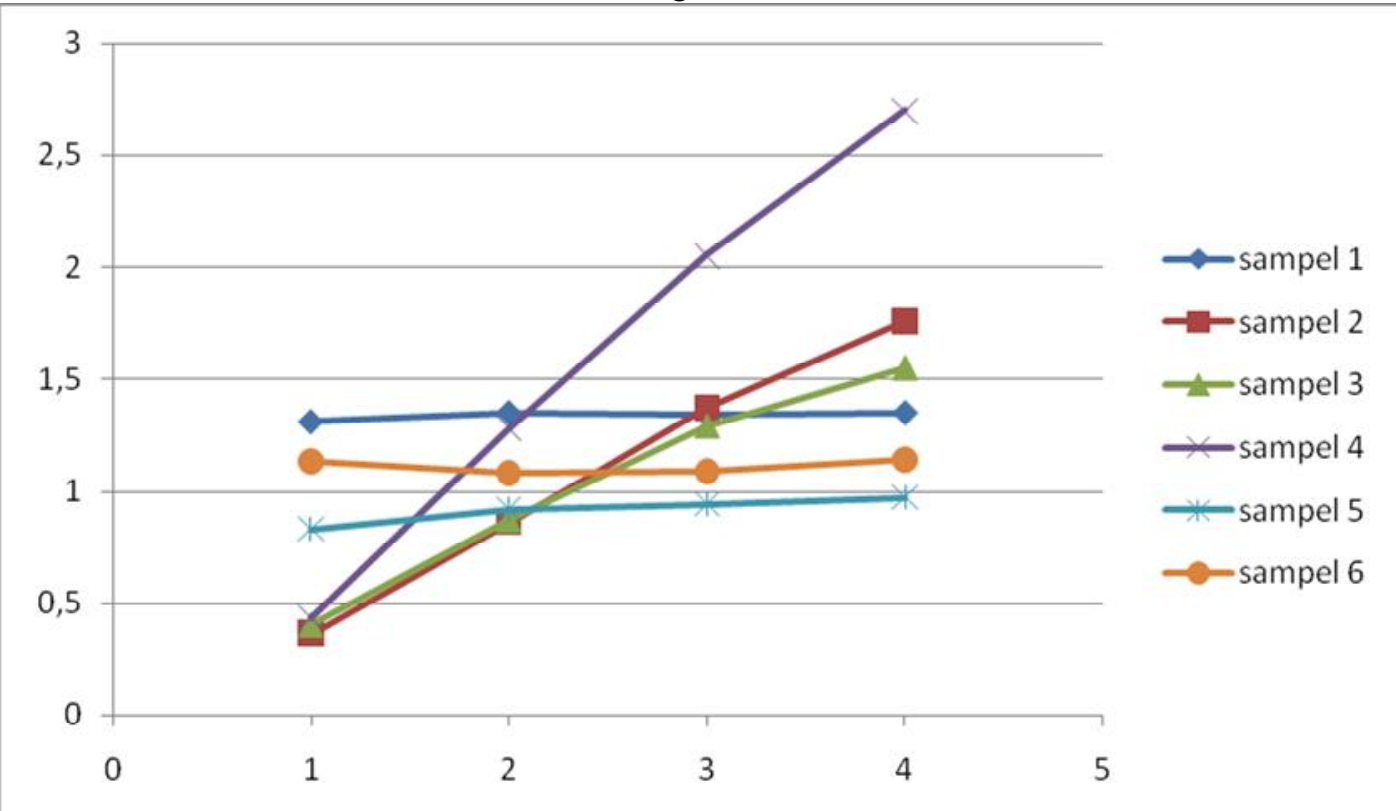

Pengukuran Indeks bias pada kasus cairan yang keruh merupakan suatu masalah yang rumit dikarenakan konsep pemantulan sudut kritis pada cairan yang keruh tidaklah jelas. Dalam penelitian ini digunakan 3 sampel jenis air yaitu, Air Limbah Tahu sebagai sampel dari air keruh berkoloid, air biasa sebagai sampel larutan dan larutan pasir sebagai sample air tersuspensi.

Alat dan bahan yang digunakan dalam penelitian ini diantaranya kotak plan paralel sebagai tempat zat cair yang akan diukur indeks biasnya (dengan ketebalan bahan $1 \mathrm{~mm}$ ), busur derajat, penggaris, kertas HVS, sterofom, alat tulis, aquades, pasir dan air limbah tahu. Parameter 
yang dalam penelitian ini yaitu indeks bias zat cair. Pengukuran indeks bias dilakukan melalui metode pembiasan menggunakan plan paralel.

Hasil darisampeltersebut didapatkan hasil yang berbeda-beda, pada sampel pertama yaitu air biasa hasilnya tidak jauh berbeda dengan hasil lab pada pengukuran indeks bias air diperoleh hasil pengukuran pada $15^{\circ}$ mendapatkan hasil sebesar 1,31 , pada $30^{\circ}$ mendapatkan hasil sebesar 1,35 dan pada $45^{\circ}$ mendapatkan hasil sebesar 1,34.

Sampel kedua yakni, air limbah tahu mendapatkan hasil bahwa sinar yang melalui dua medium berbeda yaitu udara dan air limbah (dalam percobaan) akan mengalami perubahan kecepatan dengan indikasi pembelokan sinar. Hal ini disebut pembiasan cahaya.. Semakin kecil sudut sinar datang maka pergeseran sinarnya kecil, dan apabila semakin besar sudut sinar datang maka pergeseran sinarnya akan besar pula. Apabila kerapatan medium lebih tinggi dari udara, maka sinar mengalami pembiasan mendekati garis normal. Sebaliknya, ketika sinar dari medium keluar menuju medium yang tingkat kerapatannya lebih rendah juga mengalami pembiasan, tetapi pembiasannya menjauhi garis normal. Beda halnya dengan air limbah tahu, semakin kecil sinar datang maka semakin menjauhi garis normal dengan hasil pada $15^{\circ}, 30^{\circ} 45^{\circ} 55^{\circ}$ dan $65^{\circ}$, pada $15^{\circ}$ mendapatkan hasil sebesar 0,36 , pada $30^{\circ}$ mendapatkan hasil sebesar 0,86 , pada $45^{\circ}$ mendapatkan hasil sebesar 1,37, pada $55^{\circ}$ mendapatkan hasil sebesar 1,76 dan pada $65^{\circ}$ mendapatkan hasil 2,14.

Sampel ketiga adalah campuran Limbah dan Air Biasa, mengandung 80\% limbah tahu dan $20 \%$ air biasa pada sampel hasil yang di dapatkan tidak begitu jauh dengan sampel kedua yang hanya air limbah tanpa adanya penambahan air yaitu hasil yang didapatkan sebesar, pada $15^{\circ}$ mendapatkan hasil sebesar 0,40 , pada $30^{\circ}$ mendapatkan hasil sebesar 0,87 , pada $45^{\circ}$ mendapatkan hasil sebesar 1,29, pada $55^{\circ}$ mendapatkan hasil sebesar 1,55 dan pada $65^{\circ}$ mendapatkan hasil 1,8 .

Sampel keempat adalah campuran air limbah tahu dan air yang sama-sama mengandung 50\% dari masing-masing larutan dan hasil yang didapatkan sebesar, pada $15^{\circ}$ mendapatkan hasil sebesar 0,43 , pada $30^{\circ}$ mendapatkan hasil sebesar 1, 28, pada $45^{\circ}$ mendapatkan hasil sebesar 2,05 , pada $55^{\circ}$ mendapatkan hasil sebesar 2,7 dan pada $65^{\circ}$ mendapatkan hasil 3,10.

Sampel kelima adalah campuran air limbah dan air yang dimana campuran ini lebih banyak mengandung air biasa dari pada air limbah itu sendiri, yaitu mengandung sebesar air biasa $80 \%$ dan air limbah tahu 20\% dari masing-masing larutan dan hasil yang didapatkan sebesar, pada $15^{\circ}$ mendapatkan hasil sebesar 0,83 , pada $30^{\circ}$ mendapatkan hasil sebesar 0 , 92, pada $45^{\circ}$ mendapatkan hasil sebesar 0,94 , pada $55^{\circ}$ mendapatkan hasil sebesar 0,97 dan pada $65^{\circ}$ mendapatkan hasil 1.

Pada sample terakhir yaitu, larutan pasir sebagai air keruh yang berkoloid mendapatkan hasil sebesar, pada $15^{\circ}$ mendapatkan hasil sebesar 1,13 , pada $30^{\circ}$ mendapatkan hasil sebesar 1,08 , pada $45^{\circ}$ mendapatkan hasil sebesar 1,09, pada $55^{\circ}$ mendapatkan hasil sebesar 1,14 dan pada $65^{\circ}$ mendapatkan hasil 1,15 .

Perbedaan indeks bias dari tiap-tiap sampel disebabkan oleh kecepatan laju cahaya pada masing-masing medium (sampel berbeda-beda), dimana laju cahaya pada kecepatan vakum lebih cepat dari pada laju cahaya ketika melewati suatu medium. Dalam hal ini dapat dilihat pada sampel 1, 4 dan 6 . Perlambatan ini terjadi karena dalam medium terjadi penyerapan atau absorbs 
dari hamburan cahaya saat bergerak dari suatu molekul ke molekul lainnya.Untuk penentuan indeks bias sampel maka digunakan hukum snellius.

Sampel limbah air tahu tidak berlaku demikian karena hasil data yang didapatkan menunjukan bahwa semakin kecil sudut datang maka semakin besar sudut bias hal ini bisa disebabkan oleh sifat dari kekeruhan air dan kekentalan dari air limbah tersebut, namun ketika air limbah di beri tingkatan konsentrasi air biasa maka terjadi perubahan data yang sedikit signifikan. Layaknya pada larutan limbah yang di beri tambahan air sebanyak 80 dari banyaknya air limbah maka hasil yang didapatkan berbading jauh dari air limbah tanpa adanya penambahan air. Sudut datang dan sudut bias mendekati garis normal.

\section{KESIMPULAN}

Sinar melewati medium yang berbeda yaitu dari udara ke air menyebabkan sinar mengalami pembelokkan atau pembiasan.Kekeruhan adalah ukuran kejernihan relatif suatu cairan. Ini adalah karakteristik optik dari air dan merupakan pengukuran jumlah cahaya yang tersebar oleh material di dalam air ketika cahaya disinari melalui sampel air. Semakin kecil sudut sinar datang maka semakin tinggi intensitas cahaya yang tersebar dan semakin menjauhi garis normal yang di sebabkan oleh tingkat kekeruhannya.Sinar melewati medium yang memiliki indeks bias yang berbeda.Semakin besar sudut datang (i) maka akan semakin besar pula sudut bias.

\section{DAFTAR PUSTAKA}

Adnan, Yulinar \& Supardi. . (2013). Perhitungan Sudut Deviasi Spektrum Sinar Matahari dalam Air dan Cermin Datar. Prosiding Semirata FMIPA Universitas Lampung, . Lampung: Universitas Lampung.

Burnett., D. B. ( 1927). The Relation between Refraction Index and Density. Clare Collage.

Murdaka, B., Karyono \& Supriyatin. (2010.). Penyetaraan Nilai Viskositas terhadap Indeks Bias pada Zat Cair Bening. . Jurnal Berkala Fisika. , 1-11.

Swanson, H.A., and Baldwin, H.L . (1965). A Primer on Water Quality. U.S.

Shafudah, N. H. (2015). Measurement And Comparison of Refractive Index Of The Water Samples Collected From Different Surface Water Sources . In Namibia. : The University of Namidia.

Utami, N. D. (2015). Pembiasan Cahaya. Jurnal Pembiasan Cahaya. , 56-62.

Zamroni, A. (2013.). Pengukuran Indeks Bias Zat Cair Melalui Metode Pembiasan Menggunakan Plan Paralel. Pengukuran Indeks Bias Zat Cair. 